Eur. J. Clin. Chem. Clin. Biochem.

Vol. 31, 1993, pp. 667-674

(C) 1993 Walter de Gruyter \& Co.

Berlin - New York

\title{
Mechanism of Action of Methotrexate: Experimental Evidence that Methotrexate Blocks the Binding of Interleukin $1 \beta$ to the Interleukin 1 Receptor on Target Cells
}

\author{
By Marlene Brody, Ingrid Böhm and R. Bauer \\ Center of Flow Cytometry, Department of Dermatology, University of Bonn, Germany
}

(Received April 26/July 5, 1993)

Summary: Interleukin 1, a multifunctional cytokine, plays a central role in inflammatory processes and induction of the immune response. Target cells possess 200-5000 (or more) interleukin 1 receptors per cell, but they exhibit a full biological response when only $1-2 \%$ of these receptors are occupied by interleukin $1 \alpha$ or $1 \beta$. Methotrexate has been reported to be beneficial in several inflammatory and autoimmune diseases. On the other hand, many of these diseases are known to share an overproduction of interleukin 1 . It has been demonstrated that methotrexate has no influence on the interleukin 1 synthesis, so we focused our attention on the ability of methotrexate to interfere with the binding of interleukin $1 \beta$ to the interleukin 1 receptor. The experiments were performed on monocytes, lymphocytes and granulocytes using a recombinant human cytokine probe. Methotrexate led to an astonishing decrease in the binding of interleukin $1 \beta$ to the interleukin 1 receptor of peripheral blood cells, whereas methylprednisolone and indomethacin were not inhibitory. The inhibitory effect of methotrexate was dose dependent. An excess of interleukin $1 \beta$ abolished the inhibition of cytokine binding by methotrexate. We also demonstrated that methotrexate does not affect the integrity of the interleukin 1 receptor or of the target cells. Our results demonstrate that methotrexate blocks the interleukin $1 \beta$-interleukin 1 receptor pathway. Methotrexate is therefore another interleukin 1 inhibitor and a clinically efficient anticytokine.

\section{Introduction}

Interleukin 1 is represented by two distinct cytokines, interleukin $1 \alpha$ and interleukin $1 \beta$ polypeptides, which bind to the same receptors, interleukin 1 receptor type I and interleukin 1 receptor type II. The two cytokines have identical biological properties.

Binding studies in a variety of cells have shown that interleukin $1 \alpha$ exhibits a greater affinity to the interleukin 1 receptor type I $\left(M_{\mathrm{r}} 80000\right)$ and interleukin $1 \beta$ exerts a greater affinity to the interleukin 1 receptor type II $\left(M_{\mathrm{r}} 60000\right)$. The interleukin 1 receptor type I is found on T-cells, fibroblasts, keratinocytes, endothelial cells and chondrocytes; the interleukin 1 receptor type II is found on B-cells, neutrophils and monocytes (1). It has been reported that target cells possess 200-5000 (ore more) interleukin 1 receptors per cell but exert a full biological effect when only $1-2 \%$ of these receptors are occupied by interleukin 1 (2).

Two molecular biological mechanisms control the activity of interleukin 1: the adjustment of interleukin 1 synthesis and the regulation of signal transduction by interference with the binding of interleukin 1 to its receptor on target cells. The binding of interleukin 1 to the interleukin 1 receptor is prevented by natural interleukin 1 inhibitors such as the interleukin 1 receptor antagonist, which competes with interleukin 1 for the interleukin 1 receptor, or by the soluble interleukin 1 receptor which binds directly to interleukin 1 $(1,2)$. Other described interleukin 1 inhibitors are epidermal cell-contra-interleukin 1 which is induced by UV-B radiation in the epidermis (3), and the cytokine transforming growth factor $\beta 1$ (4). Because of 
the great affinity of the target cells for interleukin 1, an excess of interleukin 1 receptor antagonist must be present to block the interleukin 1-induced biological responses.

Independent of its antiproliferative effect in high doses $(5,6)$, methotrexate (4-amino-4-deoxy-N10-methylpteroylglutamic acid) exerts well documented antiinflammatory and immunoregulatory activity in low doses, but its mechanism of action is not clear.

While methotrexate has no demonstrable influence on the interleukin 1 production (7) and at the same time there are clinical and experimental references to an antiinflammatory function of methotrexate, the question arises whether it might act via interleukin 1 antagonism. We focussed our attention on the binding of interleukin $1 \beta$ to its receptor on target cells in the presence of methotrexate, in order to examine whether methotrexate has the ability to block the interleukin 1interleukin 1 receptor pathway.

\section{Materials and Methods}

\section{Materials}

Phycoerythrin labelled human interleukin $1 \beta$ was obtained from Hermann Biermann Diagnostica GmbH Bad Nauheim, Germany, methotrexate was obtained from Lederle GmbH \& Co. Wolfratshausen, Germany, methylprednisolone (Urbason ${ }^{\circledR}$ ) from Hoechst AG Frankfurt a.M., Germany, indomethacin (Vonum ${ }^{\circledR}$ ) from Econerica $\mathrm{GmbH}$ Puchheim/München, Germany. Phycoerythrin-labelled monoclonal antibodies: mouse anti-human $\mathrm{CD} 3$, mouse anti-human CD4, mouse anti-human CD11b, mouse anti-human CD14, mouse anti-human CD19, mouse anti-human CD25 were obtained from Becton Dickinson GmbH Heidelberg, Germany. The flow cytometer (FACScan) apparatus and FACS lysing solution were from Becton Dickinson $\mathrm{GmbH}$ Heidelberg, Germany.

\section{Cytokine probe - principle of the method}

Cells were incubated with phycoerythrin labelled interleukin $1 \beta$ which bound to specific cellular interleukin 1 receptors. Unbound interleukin $1 \beta$ was then washed from the cells. Cells expressing the interleukin 1 receptor were fluorescently stained. The intensity of fluorescence was directly proportional to the density of the receptors. Phycoerythrin labelled interleukin $1 \beta$ binding receptor density was then determined by FACS analysis using $488 \mathrm{~nm}$ wavelength laser excitation. The specificity of the reaction of phycoerythrin labelled interleukin $1 \beta$ was demonstrated by blocking the staining of the cells by pretreatment with a 100 -fold molar excess of unlabeled interleukin $1 \beta$ prior to incubation with phycoerythrin labelled interleukin $1 \beta$.

The binding ability of interleukin $1 \beta$ to the interleukin 1 receptor on monocytes, lymphocytes and granulocytes was analysed in blood samples from twenty-five healthy volunteers as follows:

\section{Interleukin $1 \beta$ binding assay}

Whole blood was collected in evacuated tubes containing EDTA as the anticoagulant. Phycoerythrin labelled interleukin $1 \beta(32.5$ $\mathrm{ng}$ ) was added to $25 \mu \mathrm{l}$ EDTA blood for a total reaction volume of $50 \mu$ and incubated for 60 minutes at $4^{\circ} \mathrm{C}$. The crythrocytes were then lysed using FACS lysing solution. Unbound phycoerythrin labelled interleukin $1 \beta$ was removed by washing the cells with $0.02 \mathrm{~mol} / \mathrm{l}$ phosphate buffered $9 \mathrm{~g} / \mathrm{l}$ saline solution $\mathrm{pH} 7.4$ and by centrifuging the cells at $1000 \mathrm{~g}$ for five minutes. The cells were resuspended in phosphate buffered saline for final FACS analysis.

\section{Interleukin $1 \beta$ inhibitory assay}

Phycoerythrin labelled interleukin $1 \beta(32.5 \mathrm{ng})$ was added to $500 \mu \mathrm{g}$ methotrexate or to $50 \mu \mathrm{g}$ indomethacin or to $800 \mu \mathrm{g}$ methylprednisolone in a total reaction volume of $25 \mu \mathrm{l}$ and incubated for 30 minutes at room temperature. The methotrexate sample was incubated in opaque tubes because methotrexate is photosensitive. Following this incubation, $25 \mu$ EDTA blood was added to give a total reaction volume of $50 \mu$ land incubated for 60 minutes at $4^{\circ} \mathrm{C}$. The assay was then continued as described above. The inhibitory assay was repeated using $12.5-$ $500 \mu \mathrm{g}$ methotrexate, $200-1200 \mu \mathrm{g}$ methylprednisolone or $50-$ $120 \mu \mathrm{g}$ indomethacin. The interaction of methotrexate, methylprednisolone or indomethacin with the binding of interleukin $1 \beta$ to its receptor on monocytes, lymphocytes and granulocytes was determined from the decrease in intensity of fluorescence and percentage of cells binding interleukin $1 \beta$.

Controls were carried out with a panel of phycoerythrin-conjugated mouse anti-human monoclonal antibodies against various leukocyte differentiation antigens and $500 \mu \mathrm{g}$ methotrexate, in order to determine whether methotrexate can quench the fluorescence signal of phycoerythrin.

\section{Interleukin 1 receptor integrity assay}

An inhibitory assay was started using $32.5 \mathrm{ng}$ phycoerythrin labelled interleukin $1 \beta, 500 \mu \mathrm{g}$ methotrexate and $25 \mu \mathrm{l}$ EDTA blood as described above. The assay was stopped after the incubation step with the blood for 60 minutes at $4^{\circ} \mathrm{C}$. The cells were washed 3 times with phosphate buffered saline, then resuspended in phosphate buffered saline for a total volume of $25 \mu \mathrm{l}$ and taken for the binding assay as described above. The results were compared with those of the previously performed inhibitory and binding assays.

\section{Flow cytometric analysis}

For each measurement $10^{4}$ cells were acquired. The quantitative presentation of the data was demonstrated in dot-plot analysis and histograms. The intensity of the fluorescence and the percentage of interleukin $1 \beta$ binding cells were calculated.

\section{Statistical analysis}

The data from twenty-five binding and inhibitory assays was checked for significance as follows:

The displacement of the fluorescence intensity due to a diminished phycoerythrin labelled interleukin $1 \beta$ binding to its receptor, presented quantitatively in form of histograms, was analysed using the Kolmogorov-Smirnov statistical test (8). Starting from the two histograms for the same sample before and after additional methotrexate, we computed the sample probability distribution functions $\mathrm{Fn}_{1}(\mathrm{x})$ and $\mathrm{Fn}_{2}(\mathrm{x})$, given by:

$$
F n_{1}\left(x_{r}\right)=\sum_{x=x_{0}}^{x_{r}} f n_{1}(x) \text { and } F n_{2}\left(x_{r}\right)=\sum_{x=x_{0}}^{x_{r}} f n_{2}(x)
$$

where $x_{r}$ is the abscissa value. In a flow system the abscissa represents 1024 channels, so that $0 \leq x_{r} \leq 1024$. The graphical presentation of $F n_{1}\left(x_{r}\right)$ and $F n_{2}\left(x_{r}\right)$ are the summation curves. 
The statistic D was also calculated. D indicates graphically the maximum vertical deplacement between the two summation curves and is given by: $\mathrm{D}=\max \left[F n_{1}(\mathrm{x})-\mathrm{Fn}_{2}(\mathrm{x})\right]$.

The Kolmogorov-Smirnov statistical test was applied separately for monocytes, lymphocytes and granulocytes.

Data for the mean intensity of fluorescence of the phycoerythrin labelled interleukin $1 \beta$ binding monocytes, lymphocytes and granulocytes from binding and inhibitory assays were analysed by linear regression. The statistical significance of the regression coefficients and of the statistical $D$ were evaluated by using the two-sided Student t test.

\section{Results}

Expression of the interleukin 1 receptor type II by monocytes, lymphocytes and granulocytes in peripheral blood

The lymphocytes in peripheral blood show some binding of interleukin $1 \beta$, and therefore express the interleukin 1 receptor type II. The percentage of interleukin $1 \beta$-binding lymphocytes of healthy volunteers varies from 3.1 to $32.4 \%$. Distinctly more interleukin $1 \beta$ was bound by monocytes than by lymphocytes. Monocytes regulary expressed the interleukin 1 receptor type II, reaching range of $59.6-93.7 \%$ of the cells.

Only $0.2-6.9 \%$ of the granulocytes of healthy volunteers expressed the interleukin 1 receptor type II.

Methotrexate, but not methylprednisolone or indomethacin, blocks the binding of interleukin $1 \beta$ to the interleukin 1 receptor on monocytes, lymphocytes and granulocytes in peripheral blood

The binding of interleukin $1 \beta$ to the interleukin 1 receptor of all monocytes, lymphocytes and granulocytes was markedly decreased in the presence of $500 \mu \mathrm{g}$ methotrexate. Both the percentage and intensity of fluorescence of the interleukin $1 \beta$-binding cells were decreased (fig. 1a, b). The decrease of fluorescence intensity as visualized by histograms (fig. $2 a, b$, c) was analysed with the Kolmogorov-Smirnov statistical test for the analysis of histograms from flow systems.

The results of computed sample probability distribution functions starting from the histograms in figures $2 a, b, c$ are seen in figures $3 a, b, c$. They demonstrate the displacement of the fluorescence intensity due to diminished phycoerythrin labelled interleukin $1 \beta$ binding to the interleukin 1 receptor on target cells in the presence of $500 \mu \mathrm{g}$ methotrexate. The displacement between the two summation curves was statistically significant at $\mathrm{p}<0.0001$ for monocytes,

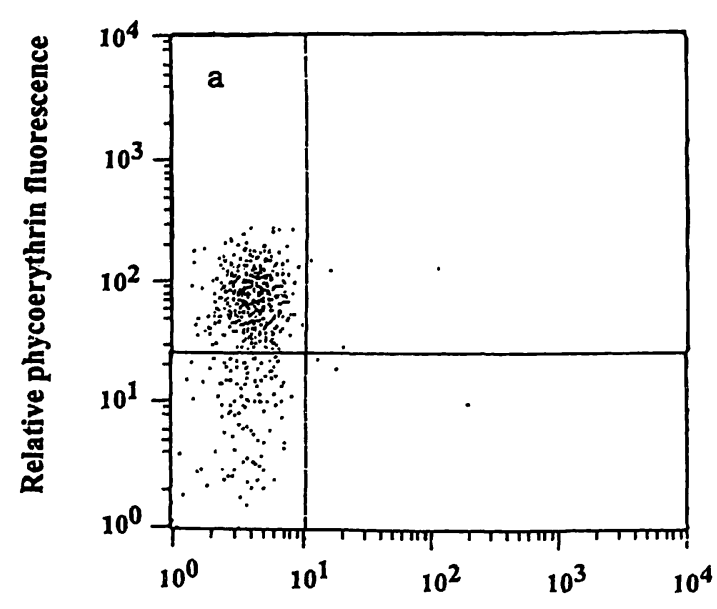

Relative phycoerythrin fluorescence

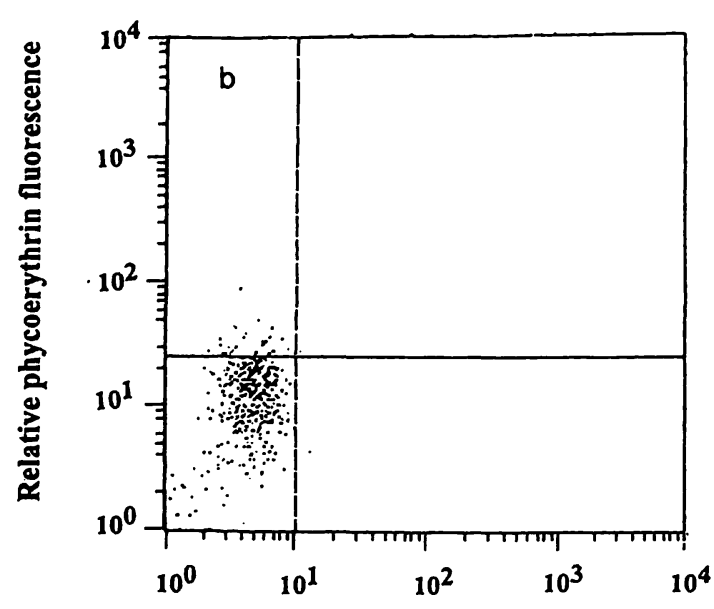

Relative phycoerythrin fluorescence

Fig. 1. Dot-plot analysis of phycoerythrin labelled interleukin $1 \beta$-binding monocytes without methotrexate (a) and with $500 \mu \mathrm{g}$ methotrexate (b).

lymphocytes and granulocytes. In addition, the mean fluorescence intensity of phycoerythrin labelled interleukin $1 \beta$ binding cells before and after $500 \mu \mathrm{g}$ methotrexate application was measured in all twenty-five binding and inhibitory assays. The data was analysed by linear regression, separately for monocytes, lymphocytes and granulocytes (fig. $4 a, b, c)$. The linear regression indicated a coefficient $r=0.7(p<0.001)$ for monocytes, $r=0.74(p<0.001)$ for lymphocytes and $r=0.78(p<0.001)$ for granulocytes, thus demonstrating the constant and significant ability of methotrexate to block the binding of interleukin $1 \beta$ to its receptor.

Methylprednisolone and indomethacin had no infiuence on the binding of interleukin $1 \beta$ to its receptor in concentrations ranging from $200-1200 \mu \mathrm{g}$ for methylprednisolone and 50-125 $\mu \mathrm{g}$ for indomethacin. Controls consisting of monocytes, lymphocytes and granulocytes labelled with phycoerythrin-conjugated monoclonal antibodies against the leukocyte 

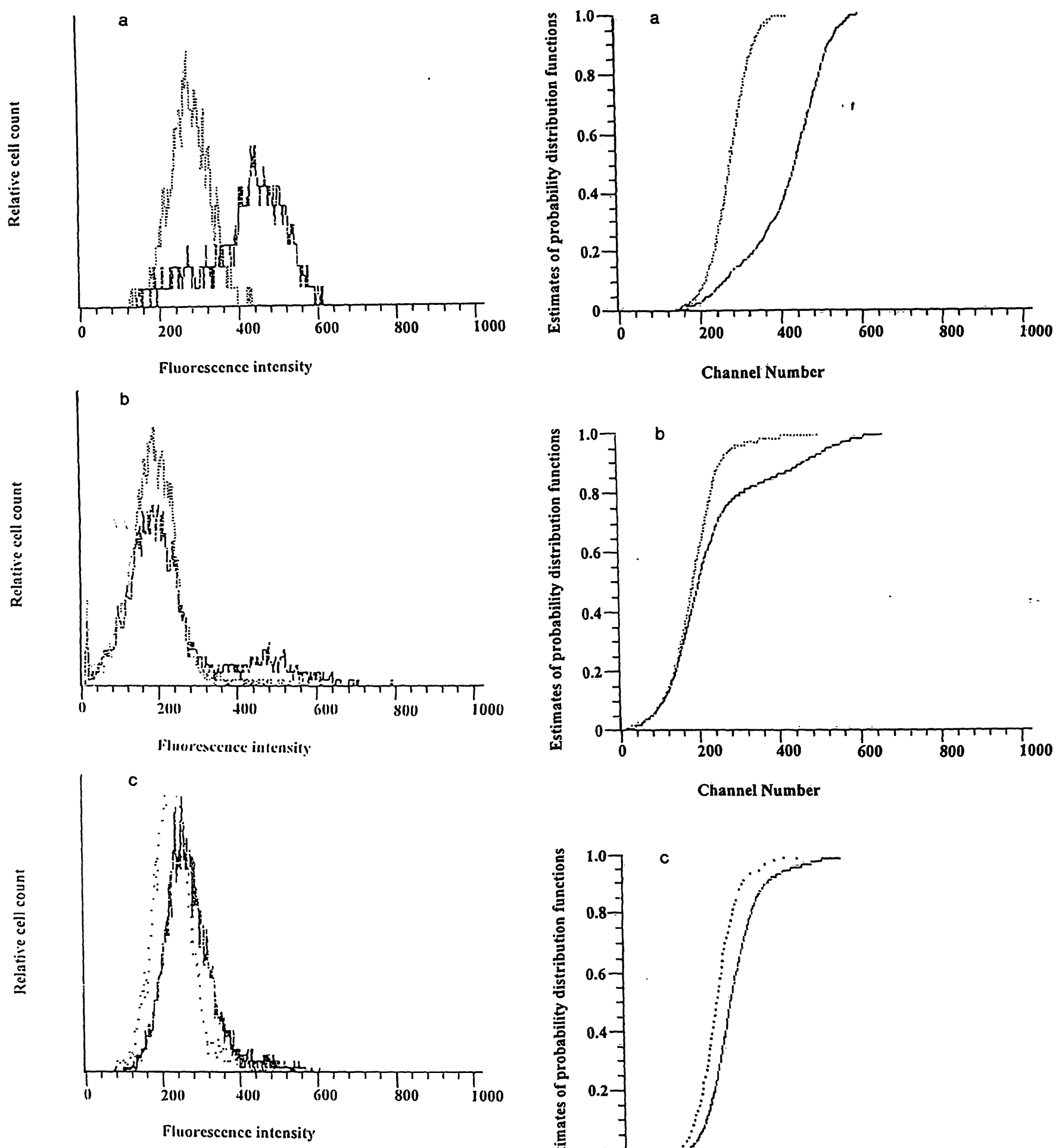

Fig. 2. Flow cytometry of cell populations stained by phycoerythrin labelled interleukin $1 \beta$. Single histograms without $(\longrightarrow)$ and with $(\cdots . \cdot)$ additional methotrexate. The decreased fluorescence intensity is due to a diminished binding of interleukin $1 \beta$ to its receptor in the presence of methotrexate (…).

a. Monocytes; b. Lymphocytes; c. Granulocytes

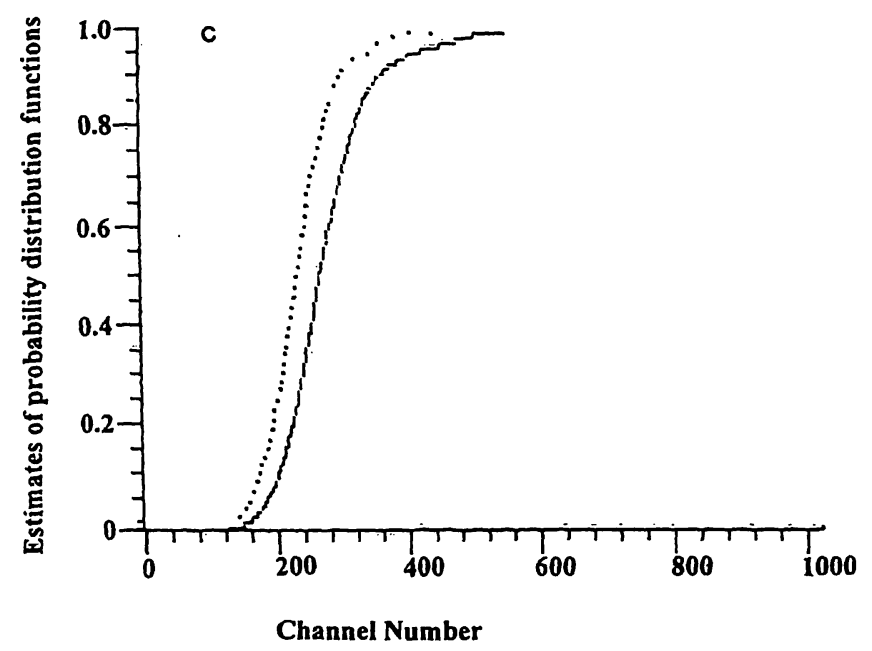

Fig. 3. Kolmogorov-Smirnov test for the analysis of the histograms. Summation curves.

a. Monocytes; b. Lymphocytes; c. Granulocytes

differentiation antigens $\mathrm{CD} 3, \mathrm{CD} 4, \mathrm{CD} 11 \mathrm{~b}, \mathrm{CD} 14$, $\mathrm{CD} 19, \mathrm{CD} 25$ with and without additional methotrexate showed no changes of fluorescence intensity when $500 \mu \mathrm{g}$ methotrexate and phycoerythrin-conjugated monoclonal antibodies were used simultaneously. These controls showed that methotrexate does not quench the fluorescence signal of phycoerythrin.

The ability of methotrexate to interfere with the binding of interleukin $1 \beta$ to the interleukin 1 receptor on target cells was dose dependent (fig. 5). The analysed quantity was the percentage of interleukin $1 \beta$ binding cells. The cell population stained by phycoerythrin labelled interleukin $1 \beta$ without methotrexate was regarded as $100 \%$ positive. Using methotrexate concen- 

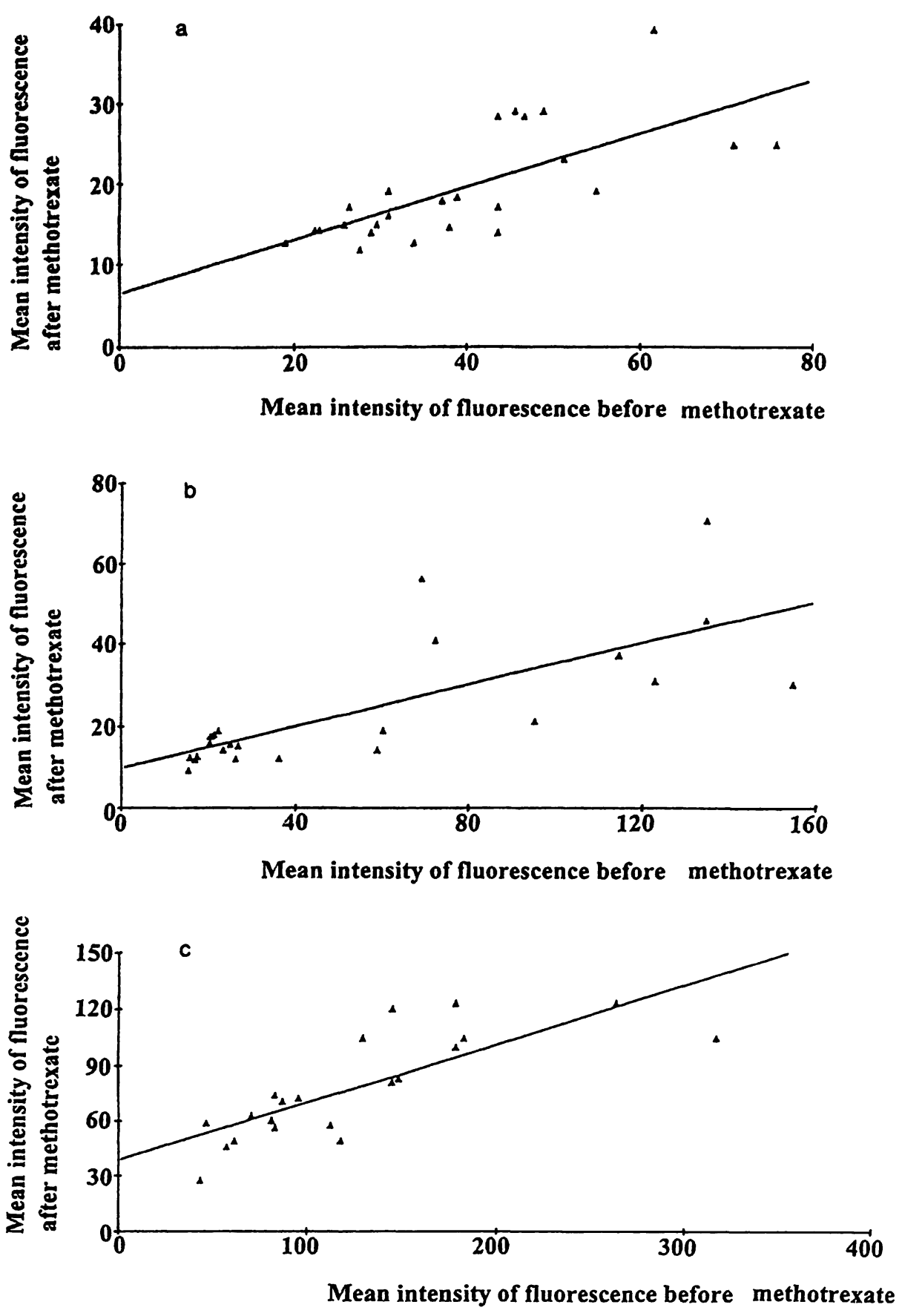

Fig. 4. Analysis of the data by means of linear regression. Investigated quantity: the mean intensity of fluorescence of phycoerythrin labelled interleukin 1 $\beta$-binding cells.
a. Monocytes
Regression equation: $y=6.4+0.33 x$
b. Lymphocytes
Regression equation: $\mathrm{y}=9.98+0.25 \mathrm{x}$
c. Granulocytes
Regression equation: $\mathrm{y}=38.45+0.31 \mathrm{x}$.

trations of $12.5-500 \mu \mathrm{g}$ in the inhibitory assay, we demonstrated that a $50 \%$ inhibition of the interleukin $1 \beta$ binding is achieved by $75 \mu \mathrm{g}$ methotrexate for lymphocytes, by $287.5 \mu \mathrm{g}$ methotrexate for granulocytes and by $350 \mu \mathrm{g}$ methotrexate for monocytes. The assay indicated not only a dose dependent effect of methotrexate on the binding of interleukin $1 \beta$ to the interleukin 1 receptor but also a dependence on the cell population. The interleukin $1 \beta$ antagonism of methotrexate was first perceptible on lymphocytes then on granulocytes and then on monocytes.
The effect of methotrexate was reversible. Incubation of $500 \mu \mathrm{g}$ methotrexate with a sixfold interleukin $1 \beta$ concentration in the inhibitory assay abolished the ability of methotrexate to block the activity of the cytokine. In these circumstances, interleukin $1 \beta$ became bound to the interleukin 1 receptor on target cells. The fluorescence intensity and percentage of interleukin $1 \beta$ binding cells were comparable to those in the original binding assay. 


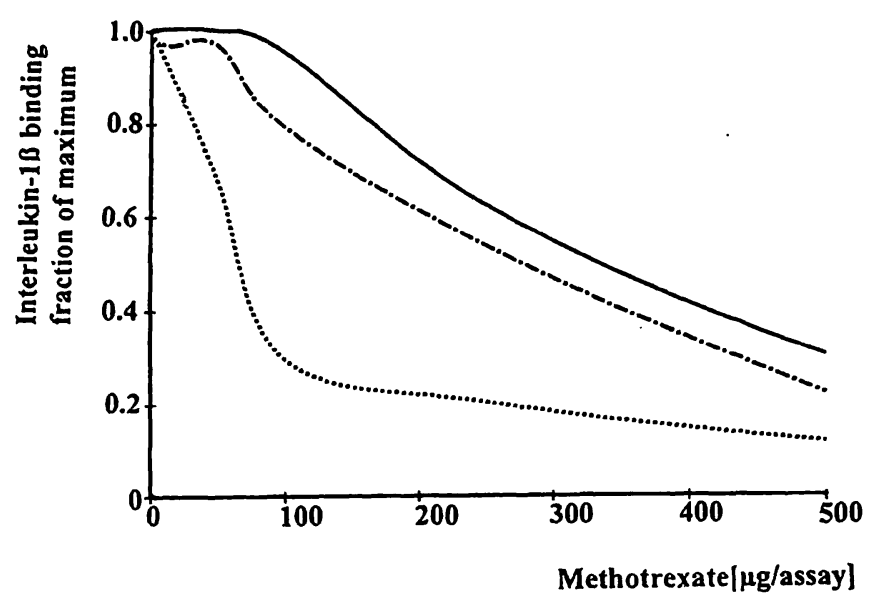

Fig. 5. The effect of methotrexate on the binding of interleukin $1 \beta$ to its receptor is dose-dependent.

Analysed quantity: percentage of phycoerythrin labelled interleukin $1 \beta$-binding cells

-.- Granulocytes

----- Lymphocytes

Monocytes

Methotrexate blocks the activity of interleukin $1 \beta$ without affecting the integrity of the interleukin 1 receptor on target cells

In the interleukin 1 receptor integrity assay we demonstrated that monocytes, lymphocytes and granulocytes which bound very small amounts of interleukin $1 \beta$ in the presence of methotrexate, bound interleukin $1 \beta$ again after removing methotrexate and interleukin $1 \beta$ from the solution. The binding, measured by fluorescence intensity and percentage of cells stained by phycoerythrin labelled interleukin $1 \beta$, was practically identical to that in the original binding assay. Thus, $500 \mu \mathrm{g}$ methotrexate are able to block the binding of $32.5 \mathrm{ng}$ interleukin $1 \beta$ without affecting the integrity of the interleukin 1 receptor or of the target cells.

\section{Discussion}

We investigated the binding of interleukin $1 \beta$ to the interleukin 1 receptor on the cell surface of monocytes, lymphocytes and granulocytes of healthy volunteers in the presence of methotrexate, by means of phycoerythrin-conjugated cytokine and FACS analysis. According to the literature, the interleukin 1 receptor type II has regulary been found on monocytes, whereas, contrary to our expectations, it was expressed by only $0.2-6.9 \%$ of granulocytes.

The binding studies provided direct experimental evidence that methotrexate blocks the binding of interleukin $1 \beta$ to its receptor on target cells. This effect is dose-dependent. Therefore methotrexate is able to control the interleukin 1 activity by blocking signal transduction between cytokine and target cells. Methotrexate is therefore another interleukin 1 inhibitor such as interleukin 1 receptor antagonist, soluble interleukin 1 receptor or epidermal cell-contra-interleukin 1. Furthermore, the results of the interleukin 1 receptor integrity assay provided experimental evidence that methotrexate functions as an interleukin 1 inhibitor without affecting the integrity of the target cells or the interleukin 1 receptor.

Initially described as a product of activated phagocytic cells, it is now known that interleukin 1 is synthesized by a wide variety of cells. These include circulating blood monocytes, splenic macrophages, bone marrow adherent cells, hepatic Kupffer's cells, peritoneal macrophages, pulmonary alveolar macrophages, as well as non-phagocytic cells such as keratinocytes, Langerhans' cells of the skin, endothelial and smooth muscle cells, corneal, gingival and thymic epithelial cells, astrocytes and microglial cells in the brain, osteoclasts and synovial fibroblasts. B-cells and natural killer cells express interleukin 1. Various epithelial cells, neurons and adrenal cells from healthy subjects contain interleukin 1 (9). Its production can be stimulated by agents such as immunocomplexes, complement components, microbial products such as endotoxin, plant lectins or antigens (10). Interleukin 1 is a proinflammatory cytokine and its pyrogenic effect due to prostaglandin release is well known. Interleukin 1 is a co-growth factor for keratinocytes implicated in acanthosis (11), it stimulates fibroblasts to synthesize and release collagenase and prostaglandins and stimulates endothelial cells to upregulate adhesion molecules $(12,13)$. Interleukin 1 stimulates the immune system directly by activating lymphocytes and indirectly by inducing other cytokines. Interleukin 1 induces in T-cells the production of interleukin 2 as well as the expression of interleukin 2 receptors. Together with interleukin 4 and interleukin 6 interleukin 1 activates B-cells and contributes to the formation of antibodies. In fibroblasts, endothelial cells, macrophages and lymphocytes, interleukin 1 stimulates the production of interferons and haematopoetic colony-stimulating factors. Interleukin 1 and tumour necrosis factor $\alpha$ induce the production of each other from monocytes, fibroblasts and endothelial cells. Interleukin 1 stimulates its own production in monocytes (14), in smooth muscle cells (15) and in endothelial cells (16). This effect depends upon the concentration of interleukin 1. Furthermore interleukin 1 induces the production of interleukin 8 in dermal fibroblasts, a neutrophil-activating cytokine with a major role in psoriasis (17), and also in endothelial cells (18). Interleukin 1 is known to induce the synthesis of interleukin 3 and interleukin 6 and together 
with interleukin 2 and $\alpha$ interferon it activates the natural killer cells (19). An increased interleukin 1 production is implicated in several diseases such as rheumatoid arthritis $(9,20)$, septic shock $(1,9)$, graft versus host disease (21), transplant rejection (22), acute and chronic leukaemia $(9,23)$, psoriasis $(24$, 25 ), tuberculosis (26), leprosy (27), cutaneous T-cell lymphoma (28), inflammatory bowel disease (9) and asthma (9). Patients with systemic lupus erythematosus have a spontaneous interleukin 1 production by B-cells. B precursor cells express the interleukin 1 receptor. The findings suggest an autocrine mechanism of conversion of precursor B-cells to immunoglobulin-producing cells in which interleukin 1 plays a key role (29). Several clinical studies have shown that low dose methotrexate is efficacious in the treatment of inflammatory and autoimmune diseases such as rheumatoid arthritis (30), psoriasis and psoriatic arthritis $(31,32)$, inflammatory bowel disease (33), systemic lupus erythematosus (34), primary biliary cirrhosis (35), graft versus host disease (36), but also Sezary syndrome (37) and corticosteroid-dependent asthma (38), diseases which are meanwhile all known to share an overproduction of interleukin 1 . The onset of the antiinflammatory effect of methotrexate was rapid in all treated patients.

Although the mechanism by which high dose methotrexate alters cellular biochemical reactions and exerts its cytotoxic effect is well characterized, the mechanism by which low dose methotrexate interferes with the ongoing inflammatory and immune reactions in such a wide spectrum of diseases remained elusive. In order to demonstrate the presumed immunomodulatory effect of methotrexate several models have been elaborated. Valuable contributions were made by $\mathrm{Se}$ gal et al. (7) who observed that there was no demonstrable effect of methotrexate on interleukin 1 synthesis in vitro or in rheumatoid arthritis patients and mice treated with methotrexate. However methotrexate had an inhibitory effect on two functions of interleukin 1 in vitro. Several other studies suggest that neutrophil chemotaxis is depressed in the presence of methotrexate, indicating a direct or indirect effect of methotrexate on neutrophils with positive consequences on psoriatic lesions (39-41). Johnson et al. (42) demonstrated in an adjuvant arthritis rat model that methotrexate, indomethacin and prednisolone are efficient antiinflammatory drugs, but only methotrexate had the ability to prevent systemic activation and local accumulation of inflammatory cells, whereas indomethacin and prednisolone suppressed only the ongoing local inflammatory process.

We demonstrated that methotrexate blocks the binding of interleukin $1 \beta$ to the interleukin 1 receptor on target cells. The function of methotrexate as an interleukin 1 inhibitor explains its clinical efficiency in a wide spectrum of diseases, which in the meantime have been shown to have in common an overproduction of interleukin 1. The interleukin 1 antagonism of methotrexate leads to a rapid abolition of the ongoing stimulation of the immune system. Both the direct activation of lymphocytes and the cytokine cascade are interrupted. Because of the diversity of cells affected by interleukin 1 , methotrexate plays a key role in the therapy as an interleukin 1 inhibitor that specifically modulates the interleukin 1 response without affecting the interleukin 1 receptor or cellular functions.

\section{References}

1. Beuscher, H. U., Rausch, U. P. \& Röllinghoff, M. (1992) Die Rolle von Interleukin 1 bei Infektionen und Sepsis. Immun. Infect. 20, 128-133.

2. Bigler, C. F., Norris, D. A., Weston, W. L. \& Arend, W. P. (1992) Interleukin 1 receptor antagonist production by human keratinocytes. J. Invest. Dermatol. 98, 38-44.

3. Schwartz, T., Urbanska, A., Gschnait, F. \& Luger, T. A. (1987) UV-irradiated epidermal cells produce a specific inhibitor of interleukin activity. J. Immunol. 138, 14561463.

4. Wahl, S. M., Hunt, D. A. \& Wong, H. L. (1988) Transforming growth factor $\beta$ is a potent immunosuppressive agent that inhibits interleukin 1-dependent lymphocytes proliferation. J. Immunol. 140, 3026-3032.

5. Jolivet, J., Cowan, K. H., Curt, G. A., Clendininn, N. J. \& Chabner, B. A. (1983) The pharmacology and clinical use of methotrexate. N. Engl. J. Med. 309, 1094-1104.

6. Wang, Y. M. \& Loo, T. L. (1981) Mechanism of action of methotrexate. Cancer Bull. 33, 49-54.
7. Segal, R., Mozes, E., Yaron, M. \& Tartakovsky, B. (1989) The effects of methotrexate on the production and activity of interleukin 1. Arthritis Rheum. 32, 370-377.

8. Young, I. T. (1977) Proof without prejudice: Use of the Kolmogorov-Smirnov test for the analysis of histograms from flow systems and other sources. J. Histochem. Cytochem. 25, 935-941.

9. Dinarello, C. A. \& Wolff, S. M. (1993) The role of interleukin 1 in disease. N. Engl. J. Med. 328, 106-113.

10. Dinarello, C. A. (1984) Interleukin 1. Rev. Infect. Dis. 6, $51-95$.

11. Ristow, H. J. (1990) Interleukin 1 does not stimulate DNA synthesis of cultured human keratinocytes growth arrested in growth-factor-depleted medium. J. Invest. Dermatol. 95, $688-692$.

12. Dustin, M. L., Rothlein, R., Bhan, A. K., Dinarello, C. A. \& Springer, T. A. (1986) Induction by interleukin 1 and $\gamma$ IFN: Tissue distribution, biochemistry and function of a natural adherence molecule (ICAM-1). J. Immunol. 137, 245-254. 
13. Luger, T. A. \& Schwarz, T. (1990) Evidence for an epidermal cytokine network. J. Invest. Dermatol. 95, 1005-1033.

14. Dinarello, C. A., Ikejima, T., Warner, S. J. C., Orencole, S. F., Lonnemann, G., Cannon, J. G. \& Libby, P. (1987) Interleukin 1 induces interleukin 1 . I. Induction of circulation interleukin 1 in rabbits in vivo and in human mononuclear cells in vitro. J. Immunol. 139, 1902-1910.

15. Warner, S. J. C., Auger, J. R. \& Libby, P. (1987) Human interleukin 1 induces interleukin 1 gene expression in human vascular smooth muscle cells. J. Exp. Med. 165, 13161331.

16. Warner, S. J. C., Auger, J. R. \& Libby, P. (1987) Interleukin 1 induces interleukin 1 . II. Interleukin 1 induces production of interleukin 1 by adult human vascular endothelial cells in vitro. J. Immunol. 139, $1911-1917$.

17. Schröder, J. M., Sticherling, M., Henneicke, H. H., Preissner, W. C. \& Christophers, E. (1990) Interleukin $1 \alpha$ or TNF alpha stimulates release of three IL-8 related neutrophil chemotactic proteins in human dermal fibroblasts. J. Immunol. 144, 2223-2232.

18. Schröder, J. M. \& Christophers, E. (1989) Secretion of novel and homologous neutrophil activating peptides by LPS-stimulated human endothelial cells. J. Immunol. 142, $244-251$.

19. Aribia, N., B., Leroy, E. \& Lautz, O. (1987) Recombinant IL-2 induced proliferation of human circulating NK cells and T lymphocytes: Synergistic effects of interleukin 1 and IL-2. J. Immunol. 139, 443-451.

20. Eastgate, J. A., Symons, J. A., Wodd, N. C., Grinlinton, F. M., de Giovine, F. S. \& Duff, G. W. (1988) Correlation of plasma interleukin 1 levels with disease activity in rheumatoid arthritis. Lancet 2, 706-209.

21. Volc-Platzer, B. (1992) Graft versus host disease. Hautarzt 43, 669-677.

22. Maury, C. P. J. \& Teppo, A. M. (1988) Serum immunoreactive interleukin 1 in renal transplant recipients. Association of raised levels with graft rejection episodes. Transplantation 45, 143-147.

23. Estrov, Z., Kurzrock, A., Estey, E., Wetzlar, M., Ferrajoli, A., Harris, D., Blake, M., Gutterman, J. U. \& Talpaz, M. (1992) Inhibition of acute myelogenous leukemia blast proliferation by interleukin 1 receptor antagonist and soluble interleukin 1 receptors. Blood 79, 1938-1945.

24. Cooper, K. D., Hammerberg, C., Baadsgaard, O., Elder, J. T., Chan, L. S., Taylor, R. S., Voorhees, J. J. \& Fisher, G. (1988) Interleukin 1 in human skin: dysregulation in psoriasis. J. Invest. Dermatol. 95, 24S-26S.

25. Gomi, T., Shiohara, T., Munakata, T., Imanishi, K. \& Nagashima, M. (1991) Interleukin $1 \alpha$, tumor necrosis factor $\alpha$ and interferon $\gamma$ in psoriasis. Arch. Dermatol. 127, 827830.

26. Fujiwara, H., Kleinherz, M. E., Wallis, R. S. \& Ellner, J. J. (1986) Increased interleukin 1 production and monocyte suppressor cell activity associated with human tuberculosis. Am. Rev. Respir. Dis. 133, 73-77.

27. Watson, S., Bullock, W., Nelson, K., Shauf, V., Gelber, R. \& Jacobson, R. (1984) Interleukin 1 production by peripheral blood mononuclear cells from leprosy patients. Infect. Immun. 45, 787-789.
28. Tron, V. A., Rosenthal, D. \& Sauder, D. N. (1988) Epidermal interleukin 1 is increased in cutaneous T-cell lymphoma. J. Invest. Dermatol. 90, 378-381.

29. Tanaka, Y., Saito, K., Suzuki, H., Eto, S. \& Yamashita, U. (1989) Inhibitory effect of anti class II antibody on the spontaneous activation of B cells' in patients with systemic lupus erythematosus. Analysis with interleukin 1 production and interleukin 1 receptor expression. J. Immunol. $143,1584-1590$.

30. Kremer, J. M. \% Lee, J. K. (1988) A long-term prospective study of the use of methotrexate in rheumatoid arthritis. Arthritis Rheum. 31, 577-584.

31. Black, R. L., O'Brien, W. M. \& Van Scott, E. J. (1964) Methotrexate therapy in psoriatic arthritis. Double blind study on 21 patients. J. Am. Med. Assoc. 189, 743-777.

32. Nyfors, A. (1986) Methotrexate therapy in psoriasis and psoriatic arthritis. A review. Rheumatology 9, 60-87.

33. Kozarek, R. A., Patterson, D. J., Gelfand, M. D., Botoman, V. A., Ball, T. J. \& Wilske, K. R. (1989) Methotrexate induces clinical and histologic remission in patients with refractory inflammatory bowel disease. Ann. Intern. Med. $110,353-356$.

34. Lally, E. V. (1989) The use of methotrexate in the treatment of Reiter's syndrome, polymyositis, dermatomyositis and other connective tissue diseases. In: Methotrexate therapy in rheumatic disease (Wilke, E. S., ed.) New York Dekker, pp. $295-312$.

35. Bergasa, N. V., Hoofnagle, J. H., Axiotis, C. A., Rabin, L., Park, Y. \& Jones, E. A. (1991) Oral methotrexate for primary biliary cirrhosis, preliminary report. Gastroenterology 100, A720.

36. Storb, R., Deeg, J. H. \& Whitehead, J. (1986) Methotrexate and cyclosporine compared with cyclosporine alone for prophylaxis of acute graft versus host disease after marrow transplantion for leukemia. N. Engl. J. Med. 314, 729735.

37. Zackheim, H. S. \& Epstein, E. H. (1989) Low-dose methotrexate for the Sezary syndrome. J. Am. Acad. Dermatol. $21,757-762$.

38. Mullarkey, M. F., Lammert, J. K. \& Blumenstein, B. A. (1990) Long-term methotrexate treatment in corticosteroiddependent asthma. Ann. Intern. Med. 112, 577-581.

39. Cream, J. J. \& Pole, D. S. (1980) The effect of methotrexate and hydroxyurea on neutrophil chemotaxis. Br. J. Dermatol. $102,557-560$.

40. Lammers, A. M., van de Kerkhof, P. C. M. \& Mier, P. D. (1987) Reduction of leukotriene B4-induced intraepidermal accumulation of polymorphonuclear leukocytes by methotrexate in psoriasis. Br. J. Dermatol. 116, 667-671.

41. Ternowitz, Th., Bjerring, P., Anderson, P. H., Schörder, J. M. \& Kragballe, K. (1987) Methotrexate inhibits the human C5a-induced skin response in patients with psoriasis. J. Invest. Dermatol. 89, 192-196.

42. Johnson, W. J., Di Martino, M. J., Meunier, P. C., Muirhead, K. A. \& Hanna, N. (1988) Methotrexate inhibits macrophage activation as well as vascular and cellular inflammatory events in rat adjuvant induced arthritis. $J$. Rheumatol. 15, 745-749.

Dr. M. Brody

Department of Dermatology

University of Bonn

Sigmund-Freud-Straße 25

D-53105 Bonn

Germany 